\title{
Soil Contamination and Its Impact on Earthworm Population Number around Areas of Paradeep Phosphate Limited, Paradeep
}

\author{
Asit Kumar Behera, Dr. Aliva Patnaik \\ PhD Scholar*, Assistant Professor \\ School of Life Sciences, Sambalpur University, Jyoti Vihar, Burla
}

\begin{abstract}
Industrialization and soil contamination have been a long concern over the years by ecologist and environmentalist. Fatal consequences of industrialization over soil biota and its ecosystem continues from last two decades. Present study conducted to determine the range of soil contamination and its impact on earthworm population in the surrounding areas of Paradeep Phosphate Limited (PPL) which are very much prone towards pollution hazards. Investigation revealed the soil contamination range with its contaminants such as $\mathrm{Cd}, \mathrm{Cr}, \mathrm{Pb}, \mathrm{Hg}, \mathrm{Zn}, \mathrm{As}, \mathrm{Fe}, \mathrm{Cu}$ and $\mathrm{Ni}$. Concentration level of $\mathrm{Cd}, \mathrm{Cr}, \mathrm{Pb}, \mathrm{Hg}$ and $\mathrm{Zn}$ recorded more than maximum permissible limit where As, $\mathrm{Fe}, \mathrm{Cu}$ and $\mathrm{Ni}$ level noticed above the normal permissible limit. In all sites highest concentration of HM recorded except site E. Earthworm population also observed very low in comparison to site - E. Present investigation concluded that surrounding areas of PPL highly contaminated with heavy metals and has the direct influence over inhabiting earthworms population and significantly on its population number also.
\end{abstract}

Keywords: Industrialization, Contamination, Heavy metals, Earthworm population, Pollution

\section{Introduction}

Soil and its existing biota hold a key process of ecological balance with food chain. Any interference regarding terrestrial biota and its inhabiting environment consequences a deep setback towards soil fertility, agriculture and resource limited poor farmers. Rapid acceleration in industrialization and so called civilization of human beings enforces soil ecosystem and its organisms into a great threat since last two decades. Population explosion, food requirement in large scale, fertilizer production and its application directly or indirectly been the main cause behind the threaten status of terrestrial biota. Fertilizer industries and its product or by-product directly influence the soil ecosystem by contaminating the soil with different metals and heavy metals. Fertilizers also solely responsible for increasing or decreasing levels of soil basic nutrient from its par level. Soil heavy metal pollution is a very particular and serious concern because of its persistence and health consequences to man, his crops, and animals (Clark, 1992). Metals from anthropogenic sources form a major group of compounds involved in soil contamination (Lobersli and Steines, 1988) and these metals may eventually find their way into food chain and human's diet if such contaminated soils used continuously for agricultural purposes.

Being one of the cosmopolitan organism earthworms been used in different research areas due its various efficacy role towards human welfare. As earthworms are very much capable of adapting a very wide range of habitat and environmental fluctuation, used vastly to assess pollution level and act as a pollutant indicator now-a-days (Shin et al., 2007). Increasing soil metallic concentration particularly heavy metal due to anthropogenic activities exerts an alarming situation towards soil biota and earthworms suffer the most. Earthworms accumulate all the heavy metals and clean the soil for other soil dwelling organisms. Maenpaa et al., (2002), reported that some species of earthworms have been reported to be tolerant to a wide range of contaminants including heavy metals and can bioaccumulate them in large quantities in their tissues. Various anthropogenic activities compelling earthworms to do all these dirty works which not going to work for longer duration because heavy metal accumulation affects earthworms and its physiology continuously with no time to lapse. It is therefore important to deploy appropriate strategy in monitoring and evaluating soil pollutants and its level, especially heavy metals and take immediate remedial actions.

Paradeep Phosphate Limited (PPL) is one of the major phosphatic fertilizer companies of India and it is the largest Di-Ammonium Phosphate (DAP) fertilizer producer in Asia also. Besides manufactured fertilizers PPL also produces by-products like Phosphogypsum (PG) and for every ton of DAP production PPL produces five tones of PG as a by-product. According to Behera and Patnaik (2016), PG generally contains potentially toxic metals such as $\mathrm{Cd}, \mathrm{Cr}, \mathrm{Hg}, \mathrm{Pb}, \mathrm{As}, \mathrm{Zn}$ etc. and some radioactive elements also (uranium and thorium). These toxic metals impose hazardous effect towards terrestrial life, aquatic life and environment and hamper the quality of soil. These heavy metals are very much responsible for basic soil metallic and heavy metallic concentration variation and results biomagnifications in food chain. The present investigation very much keen to observe and assess the soil heavy metal contamination level and study the impact of heavy metals over Earthworms and its inhabiting population number. 


\section{International Journal of Science and Research (IJSR) \\ ISSN (Online): 2319-7064}

Index Copernicus Value (2013): 6.14 | Impact Factor (2014): 5.611

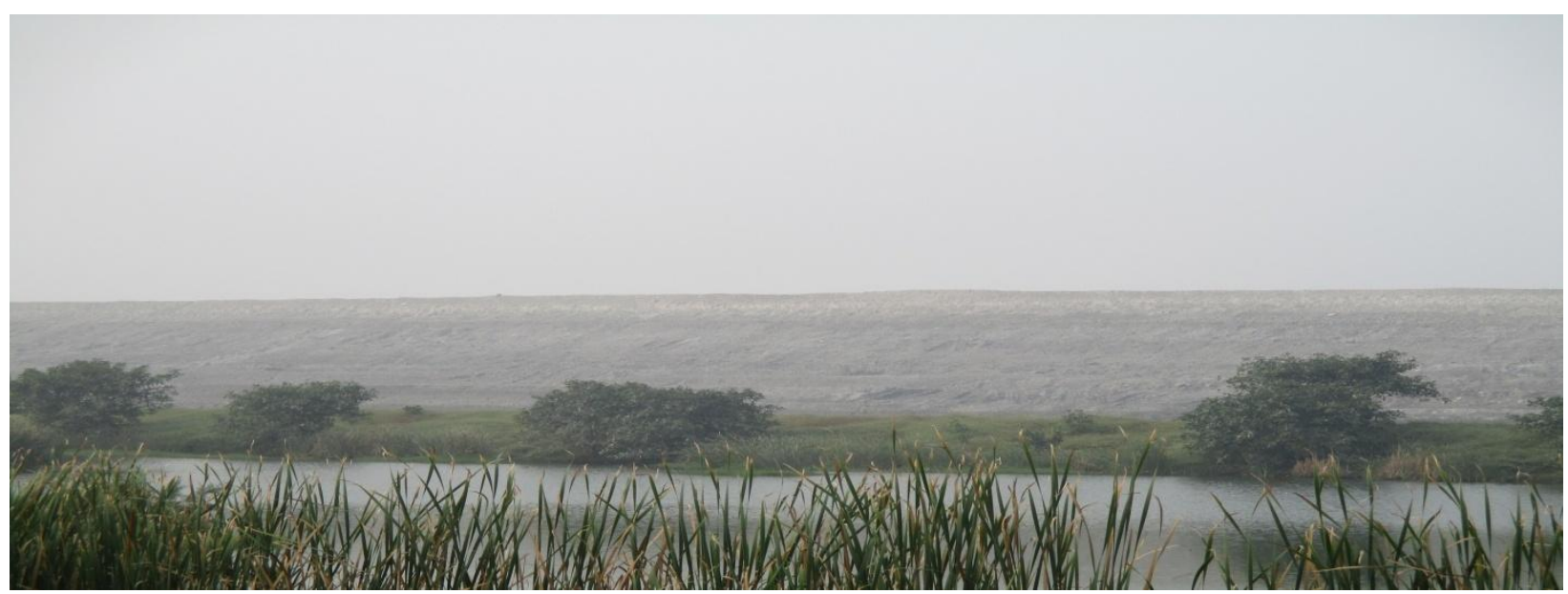

Plate 1: PG Deposits in the campus of PPL

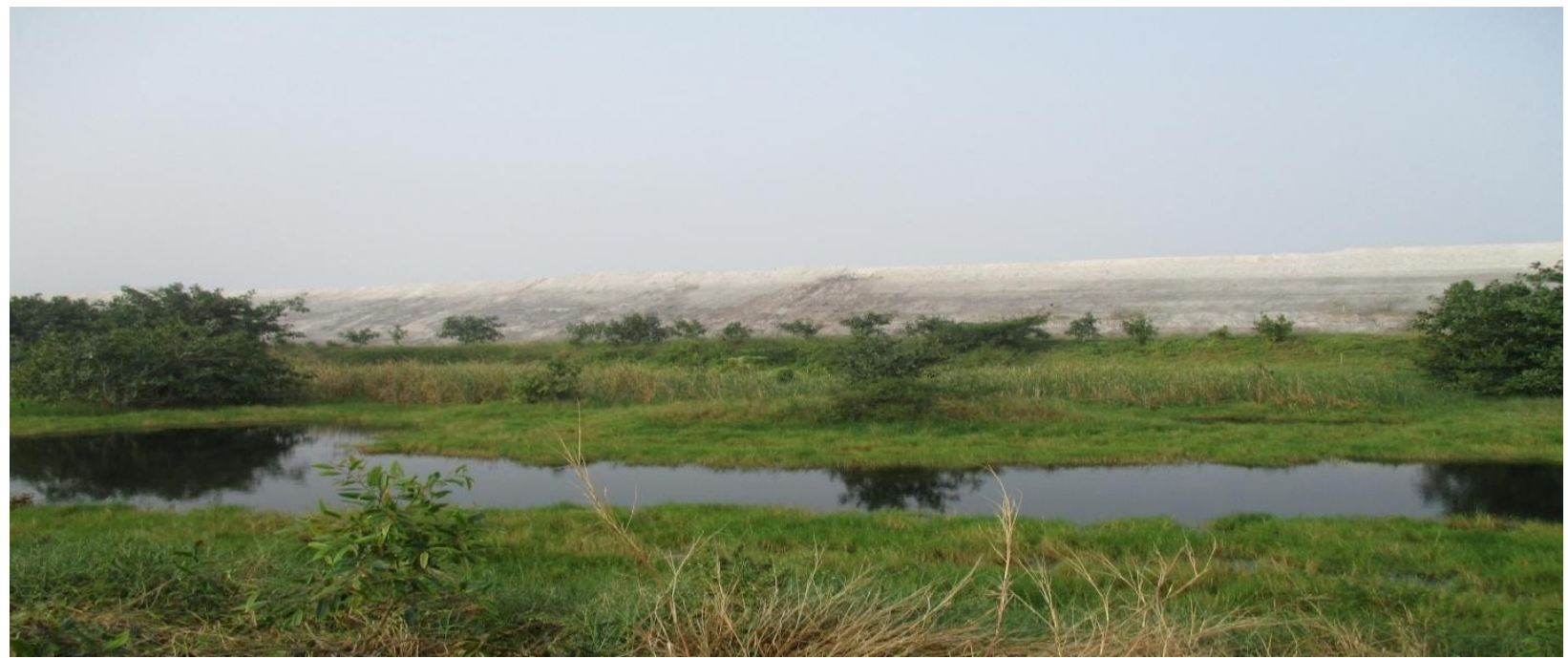

Plate 2: Mountain of PG Deposits in the campus of PPL

\section{Material and Methods}

\section{Study area}

PPL located (latitude $20^{\circ} 16^{\prime} 42^{\prime \prime} \mathrm{N}$ and longitude $86^{\circ} 38^{\prime}$ 40 "E) in port town of Paradeep of Jagatsinghpur, Odisha and it came into existence in the year 1982. Paradeep town experiences maximum temperature in May-June (48 ${ }^{\circ} \mathrm{C}$ ) and lowest $\left(15\right.$ - $\left.25^{\circ} \mathrm{C}\right)$ in December - January. This part of Odisha experience rain in two spells. First spell during the peak months of July-August followed by another spell in October-November. Winters are pleasant and more or less dry. As this part of the district belongs to coastal belt it is very much prone towards cyclone particularly in the month of October and November and experience maximum rainfall during the year. Soil types found in this part of Odisha are coastal alluvial, sandy loamy and clay loamy soils. Folks of this area are very much relying on agriculture like rice, sugarcane and betel.

\section{Earthworm Sampling and Identification}

For earthworm sampling TSBF (Tropical Soil Biology and Fertility) methodology followed. Conventional digging $(25 \mathrm{~cm} \times 25 \mathrm{~cm} \times 30 \mathrm{~cm})$ and hand sorting methods was applied for each quadrate. Earthworms were collected from different surrounding areas of PPL. Sampling areas was, 100 m (Site - A), 200 m (Site - B), 400 m (site - C), $800 \mathrm{~m}$ (site - D) and $10 \mathrm{~km}$ (Site - E, as Control) away from the plant. Earthworm sampling was done in triplicates. Adequate amount of soil also collected for the assessment of heavy metallic content. After bringing into the laboratory the earthworm sample were fixed in $70 \%$ alcohol for about 2 - 4 minutes for anesthetizing and then transferred to $10 \%$ formalin solution to preserve. For Authentic identification preserved specimen was sent to ZSI (Zoological Survey of India), Kolkata and identified.

\section{Soil Analysis}

Heavy metallic content of sampled soil was analyzed by using atomic absorption spectrophotometer Model 403 (Perkin-Elmer). 


\section{International Journal of Science and Research (IJSR) \\ ISSN (Online): 2319-7064}

Index Copernicus Value (2013): 6.14 | Impact Factor (2014): 5.611

\section{Results and Discussion}

Table 1: Concentration of heavy metals ( $\mathrm{mg} / \mathrm{kg})$ in soil

\begin{tabular}{|c|c|c|c|c|c|}
\hline \multirow{2}{*}{$\begin{array}{c}\text { Heavy } \\
\text { metals }\end{array}$} & \multicolumn{5}{|c|}{ Concentration of Heavy metals in study sites } \\
\cline { 2 - 6 } & $A$ & $B$ & $C$ & $D$ & $E$ \\
\hline $\mathbf{C d}$ & 0.08 & 0.08 & 0.05 & 0.01 & ND \\
\hline $\mathbf{C r}$ & 0.49 & 0.50 & 0.38 & 0.17 & ND \\
\hline $\mathbf{P b}$ & 0.58 & 0.55 & 0.55 & 0.41 & 0.001 \\
\hline $\mathbf{H g}$ & 0.05 & 0.02 & 0.01 & $\mathrm{ND}$ & 0.001 \\
\hline $\mathbf{Z n}$ & 13.47 & 13.54 & 12.97 & 13.11 & 3.27 \\
\hline $\mathbf{A s}$ & 7.27 & 7.57 & 7.12 & 6.11 & 1.38 \\
\hline $\mathbf{F e}$ & 0.16 & 0.20 & 0.15 & 0.15 & 0.06 \\
\hline $\mathbf{C u}$ & 1.09 & 1.24 & 0.71 & 0.55 & 0.03 \\
\hline $\mathbf{N i}$ & 4.67 & 4.32 & 4.35 & 3.49 & 0.02 \\
\hline
\end{tabular}

ND - Not Detectable

Table 2: Earthworm population in study sites

\begin{tabular}{|c|c|c|}
\hline \multicolumn{2}{|r|}{ Sites } & Total Population in number \\
\hline A & $\begin{array}{l}\text { Sampling 1- } 2 \\
\text { Sampling 2- } 0 \\
\text { Sampling 3- } 2\end{array}$ & 4 \\
\hline B & $\begin{array}{l}\text { Sampling 1-5 } \\
\text { Sampling 2- } 3 \\
\text { Sampling 3- } 6\end{array}$ & 14 \\
\hline C & $\begin{array}{l}\text { Sampling 1- } 3 \\
\text { Sampling 2- } 8 \\
\text { Sampling 3- } 6\end{array}$ & 17 \\
\hline D & $\begin{array}{c}\text { Sampling 1- } 12 \\
\text { Sampling 2- } 9 \\
\text { Sampling 3- } 14\end{array}$ & 35 \\
\hline $\mathrm{E}$ & $\begin{array}{l}\text { Sampling 1- } 34 \\
\text { Sampling 2- } 47 \\
\text { Sampling 3- } 40\end{array}$ & 121 \\
\hline
\end{tabular}

Present determined level of soil contamination very easily hamper the quality and health of soil which directly going to hammer on soil biota and the environment. Concentration level of maximum heavy metals founds high where $\mathrm{As}, \mathrm{Fe}, \mathrm{Cu}$ and $\mathrm{Ni}$ recorded under maximum tolerant level. High concentration of heavy metals recorded in site - A and lowest recorded in site - E. Cd, $\mathrm{Cr}, \mathrm{Hg}, \mathrm{Pb}$ and $\mathrm{Zn}$ concentration almost in toxic level according to World Health Organization (WHO). Nawrot et al., (2006), also found a significant level of heavy metals particularly $\mathrm{Cd}$ concentration in the soil or residence of high industrial exposure area. Cd present as an impurity in several products, including phosphate fertilizers, detergents and refined petroleum products. Application of agricultural inputs such as fertilizers, pesticides, and biosolids, disposal of industrial wastes or the deposition of atmospheric contaminants increases the total concentration of $\mathrm{Cd}$ in soils. Bioavailability of $\mathrm{Cd}$ is very biopersistent and once absorbed by an organism, remains resident for many years. Sass and Rai (1987), reported that reduced form of $\mathrm{Cr}$ has a limited hydroxide solubility and forms strong complexes with soil minerals. Cr can easily absorbed in the human body and can produce various toxic effects within cells and most $\mathrm{Cr}$ compounds are irritating to eyes, skin, and mucous membranes. Although Cr toxicity in the environment is relatively rare, it still presents some risks to human health (Intergovernmental forum on chemical safety. Six sessions, Agenda 8, 1, 2008). Pb high concentration can accumulate in different organs of human body and may lead to death. Lenntech (2009), reported that concentration level of $\mathrm{Pb}$ is generally higher than those of $\mathrm{Cd}, \mathrm{Cr}, \mathrm{Ni}$, and $\mathrm{Zn}$, and $\mathrm{Pb}$ has toxicological significance with no known biologically importance. Lead can directly affect nervous system, red blood cells, and kidneys also (Baldwin and Marshall, 1999). Zn concentrations are rising unnaturally, due to anthropogenic additions and most $\mathrm{Zn}$ is added during industrial activities. $\mathrm{Zn}$ can interrupt the activity in soils, as it negatively influences the activity of microorganisms and earthworms, thus retarding the breakdown of organic matter (Greany, 2005). High soil $\mathrm{Hg}$ concentration may adversely affect soil biotic and abiotic processes and it is most toxic in alkylated form due to easily soluble nature in water and volatile in air (Smith and Means, 1996). Maximum level of $\mathrm{Hg}$ in soil is associated with kidney damage (Scragg, 2006).

The elevated level of $\mathrm{Cd}, \mathrm{Cr}, \mathrm{Hg}$ and $\mathrm{Pb}$ may due to deposits of PG dost particle on soil by wind and water because these heavy metals are the main components of PG. Zn elevated concentration may be the results of open dumping of miscellaneous materials by the factory. Concentration of all the heavy metals observed normal or minimum at site - E (Control). Earthworm population also recorded highest (117) in site - E and population number increases considerably with maximum distance from the factory. Impact of heavy metals on inhabiting earthworm population observed significantly more in surrounding areas of PPL than other (Site - E). With increasing the distance from the factory heavy metal concentration level decreases considerably and earthworm population increases significantly and these results were very much accordance with Ipeaiyeda and Dawodu (2008) and Oyedele et al., (2008).

\section{Conclusion and Recommendations}

Every time any environmental and ecological assessments conducted over terrestrial biota in any part of the world, its current status subsequently gifting another opportunity to human beings to shift into the right track and not to alack. But stubborn human beings continue to ruin its inhabiting environment knowing its future consequences very well. Present study findings mustn't amiable for soil biota, soil fertility, environment and earthworm inhabitance and never considered as an alleviate condition to live where life can prosper without any terror. Most heavy metals are in a very elevated level and indicating a great threat towards soil, soil dwelling organism and local folks who residing and relying heavily on agriculture.

Many research outcomes recommended application of phytoremediation to eradicate soil heavy metals contamination. Wenzel et al., (1999), demonstrated that plants are very effective in cleaning up soil contaminated with heavy metals, pesticides, solvents etc.. However the actual major remedial step towards such environmental pollution will be the self consciousness of human beings towards its inhabiting surroundings and for the upcoming future generations. Regular monitoring should be done for those areas which are regarded as pollution prone and state pollution control board must remain active for such areas. If we really desire about amiable and healthy development, we have to become more sensitive towards nature and its 


\section{International Journal of Science and Research (IJSR) \\ ISSN (Online): 2319-7064 \\ Index Copernicus Value (2013): 6.14 | Impact Factor (2014): 5.611}

natural processes and must maintain a harmony with nature.

\section{References}

[1] Anderson, J.M. and Ingram J. S. I.(1993). Tropical soil Biology and Fertility: A Hand book of Method, 2nd edn., C.A.B. International, Wallingford, pp. 4476.

[2] Anyakora C., Ehianeta T. and Umukoro M.(2013) Heavy metal levels in soil samples from highly industrialized Lagos environment. African journal of environmental science and technology, 7(9) : 917-924.

[3] Brady N.C. (1984) The Nature and Properties of Soils. MacMillan Publishing Company Inc., New York, 672.

[4] Chiroma T. M., Ebewele R. O. and Hymore F.K.( 2014) Comparative assessement of heavy metal levels in soil, vegetables and urban grey waste water used for irrigation in Yola and Kano. International Refereed Journal of Engineering and Science, 3(2): 01-09.

[5] Ekpete O.A.(2013) Heavy metals distribution in soil along Iwofe Remuolumeni road. International journal of science and technology, 8(1) : 450-455.

[6] Islam M.M., Halim M.A., Safiulllah S. and Waliul S.A.M.H. and Islam S.(2009). Heavy metal (Pb, Cd, $\mathrm{Zn}, \mathrm{Cu}, \mathrm{Cr}, \mathrm{Fe}$ and $\mathrm{Mn}$ ) content in textile sludge in Gazipur, Bangladesh. Research journal of environmental seciences, 3(3): 311-315.

[7] Lokeshappa B., Shivpuri K., Tripathi V. and Dikshit A.K. (2012) Assessment of Toxic Metals in Agricultural Produce. Food and Public Health, 2(1): 24-29.

[8] Mwegoha W. J. S. and Kihampa C. (2010) Heavy metal contamination in agricultural soils and water in Dar es Salaam city, Tanzania. African Journal of Environmental Science and Technology, 4(11), 763769.

[9] Mwegoha W. J. S. and Kihampa C.(2010). Heavy metal contamination in agricultural soils and water in Dar es Salaam city, Tanzania. African journal of environmental science and technology, 4(11) : 763769.

[10] Olafisoye O.B., Adefioye T. and Osibote O.A.(2013). Heavy metals contamination of water, soil, and plants around an electronic waste dumpsite. Pol. j. environ. stud., 022(5) :1431-1439.

[11] Opaluwa O. D., Aremu M.O., Ogbo L. O., Abiola K. A., Odiba I. E., Abubakar M.M. and Nweze N.O.( 2012) Heavy metal concentrations in soils, plant leaves and crops grown around dump sites in Lafia Metropolis, Nasarawa State, Nigeria. Advances in Applied Science Research, 3 (2):780-784.

[12] Wenzel, W.W., Adriano, D.C., Salt, D., and Smith, R. 1999. Phytoremediation: A plant-microbe based remediation system. p. 457-508. In D.C. Adriano et al. (ed.) Bioremediation of contaminated soils. American Society of Agronomy, Madison, WI.

[13] World Health Organization (1993), Standard maxima for metals in Agricultural soils.

[14] Wuana R.A. and Okieimen F. E. (2011). Heavy metals in contaminated soils: A Review of Sources, Chemistry, Risks and Best Available Strategies for
Remediation. International Scholarly Research Network, Article ID - 402647.

\section{Authors Profile}

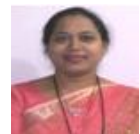

Dr. Aliva Patnaik working in the department of Life Sciences, Sambalpur University, Jyoti Vihar, Burla, Odisha, India as an Assistant Professor. She has done M.Sc. M.Phil and Ph.D with 12 years teaching experience and very much animated in the field of ecological, agricultural and environmental sciences

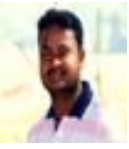

Asit Kumar Behera is a research scholar in the department of Life Sciences, Sambalpur University, Jyoti Vihar, Burla, Odisha, India. He is completed his M.Sc and M.Phil and currently pursuing Ph.D in School of Life Sciences, Sambalpur University. 